\title{
Rising Tiger and Leaping Dragon: Emerging Global Dynamics and Space for Developing Countries and Least Developed Countries
}

\section{S.K. Mohanty and Sachin Chaturvedi}

\section{Introduction}

The growth in resilient economy of Asia led by China and increasingly shared by India is a process attracting huge international attention. Chinese exports of mass production items have caused serious concern; and some studies have predicted that this might contribute to recession in the US (Palley 2004). In contrast to this negative perspective, the focus in the Asian region has been on the opportunities for economic and financial integration and the possible strategies to tap them (Kumar 2004). The expansion of these two economies may be compared with the growth of economies in the European Union. It may be noted that integration of the European Union has immensely benefited Member countries, and some of the slow-growing economies have gained strength from the regional arrangement.

The rapid growth of China and India offers great opportunities to other developing countries. Both countries have significantly liberalised their trade regimes in recent years, providing access to developing countries including the economies of the least developed countries (LDCs). As these two countries have increased their exports, their requirements for intermediate imports have also risen significantly. There are also efforts to expand investments in innovation and to involve other countries in the production of high technology goods (Chaturvedi 2005; Burton 2005). In this article, some of these issues are being analysed.
Section 2 presents broad macroeconomic facts about China and India, while Section 3 presents their trade relations and complementarities with other developing countries. Innovation and technologyrelated issues are discussed in Section 4. The conclusions are drawn in the last section.

\section{Emergence of Sino-Indian economy: basic parameters}

China's growth surge started in the late 1970s and India's in the early 1990s. The combined size of the Indian and Chinese economies in the early 1990 s was US\$681bn in constant international dollar terms in 1990 (World Bank 2005). The collective size of their economies was larger than the combined size of some of the smaller economies of Europe, such as Iceland, Luxemburg, Portugal, Finland, Greece, Denmark, Austria and Belgium. Due to rapid growth, the combined size of China and India in 2003 was relatively larger, and comparable with the combined economy of the aforesaid countries as well as Sweden, the Netherlands and Spain. In fact, the size of the two economies in 2003 was larger than any single economy in the world other than the US. By comparison with larger EU economies, the combined size of the China and India economy was larger than Spain, but smaller than that of Italy in 1990 (Figure 1). By 2003, it had surpassed the sizes of all large economies of the EU such as Italy, France, the UK and Germany.

IDS Bulletin Vol 37 No 1 January 2006 ㄷ Institute of Development Studies 


\section{Figure 1: China, India and the larger EU economies}

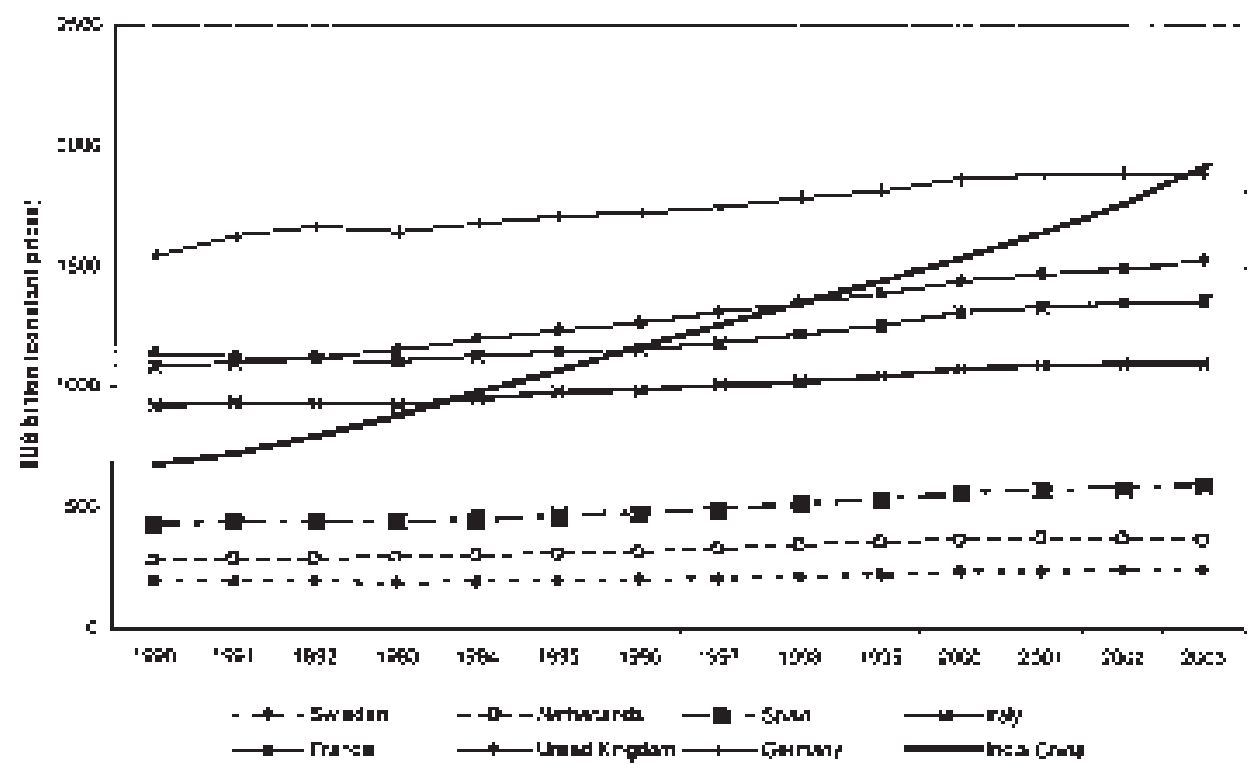

The Chinese economy is two and half times larger than that of India (Purchasing Power Parity in US\$) and is growing more rapidly. During the period 2001-03 the Chinese economy rose at the rate of 8.4 per cent per annum, whereas India expanded at the rate of 6 per cent. In both cases, rapid growth has been sustained for a number of years and has occurred in a stable environment, with low rates of inflation. Relatively speaking, the Chinese economy is much more integrated with the global economy than India. During the period 2001-03, the proportion of the traded sector in gross domestic product (GDP) was 56.5 per cent for China and 29.6 per cent for India.

Savings and investment ratios in China have shown a much more impressive increase than in India; almost double during the same period. However, the efficiency with which these savings have been utilised has been far higher in India, and much investment appears to have been wasted in China. During the period 2001-03, the average total savings ratio of China (including foreign direct investment, FDI) was 53 per cent of GDP and the economy grew at an average rate of 8.4 per cent per annum. By contrast, India grew at a rate of 6.0 per cent during the same period with the corresponding savings rate (including FDI) of just 22.4 per cent.
With sustained economic reforms, the credibility of the economies has improved, resulting in significant inflows of FDI, which has contributed further to savings ratios of both the countries.

\section{Trade complementarities with developing countries and LDCs}

\subsection{Trade aggregates}

During the last two decades, industrialisation in China and India was mostly spurred by the external sector. With deeper levels of economic liberalisation, industrial sectors are thrown open to competition with domestic as well as foreign firms. The export of mass-produced manufactures has led to the efficiency-enhancing restructuring of industries in both economies. With the surge in the demand in both export and domestic markets, industries at home have gradually streamlined their import requirements. As a result, China and India have restructured their sources of imports and exports over a period of time. In general, they have used developed countries' market for their export destination, whereas their dependence has gone up for imports from other developing countries.

However, there have been differences between China and India. Between 1985-94 and 1995-2004, the share of Chinese exports going to 
Table 1: Trends in Sino-India's trade with major trade destinations (\%)

\begin{tabular}{|c|c|c|c|c|c|c|c|c|}
\hline \multirow{3}{*}{ Destination } & \multicolumn{4}{|c|}{ India } & \multicolumn{4}{|c|}{ China } \\
\hline & \multicolumn{2}{|c|}{ Share } & \multicolumn{2}{|c|}{ Growth } & \multicolumn{2}{|c|}{ Share } & \multicolumn{2}{|c|}{ Growth } \\
\hline & $\begin{array}{l}1985- \\
94\end{array}$ & $\begin{array}{l}1995- \\
2004\end{array}$ & $\begin{array}{l}1985- \\
94\end{array}$ & $\begin{array}{l}1995- \\
2004\end{array}$ & $\begin{array}{l}1985- \\
94\end{array}$ & $\begin{array}{l}1995- \\
2004\end{array}$ & $\begin{array}{l}1985- \\
94\end{array}$ & $\begin{array}{l}1995- \\
2004\end{array}$ \\
\hline \multicolumn{9}{|l|}{ Exports } \\
\hline World & 100.0 & 100.0 & 11.6 & 12.4 & 100.0 & 100.0 & 17.4 & 18.6 \\
\hline Industrialised countries & 59.5 & 52.4 & 13.6 & 8.9 & 40.0 & 54.7 & 20.2 & 19.6 \\
\hline Developing countries & 38.6 & 45.8 & 12.2 & 16.5 & 58.4 & 45.0 & 16.4 & 17.6 \\
\hline Africa & 2.2 & 4.8 & 29.5 & 20.9 & 1.8 & 1.7 & 22.1 & 25.2 \\
\hline Asia & 14.5 & 23.1 & 21.0 & 16.6 & 46.3 & 34.9 & 19.7 & 16.1 \\
\hline Europe & 12.5 & 3.9 & 61.9 & 9.5 & 5.3 & 3.1 & 13.1 & 25.7 \\
\hline Middle East & 8.8 & 12.0 & 12.4 & 18.4 & 3.9 & 2.8 & 4.5 & 21.0 \\
\hline Western Hemisphere & 0.6 & 2.0 & 40.3 & 21.7 & 1.2 & 2.6 & 25.7 & 23.1 \\
\hline \multicolumn{9}{|l|}{ Imports } \\
\hline World & 100.0 & 100.0 & 6.3 & 15.3 & 100.0 & 100.0 & 17.6 & 18.4 \\
\hline Industrialised countries & 56.4 & 43.1 & 6.6 & 11.3 & 56.2 & 48.3 & 15.8 & 14.0 \\
\hline Developing countries & 42.1 & 43.3 & 8.0 & 14.1 & 41.4 & 48.1 & 22.4 & 21.9 \\
\hline Africa & 3.7 & 6.3 & 16.6 & 15.3 & 0.6 & 1.6 & 15.1 & 39.7 \\
\hline Asia & 10.7 & 18.3 & 12.6 & 21.0 & 30.8 & 37.2 & 26.4 & 21.4 \\
\hline Europe & 6.7 & 2.7 & 9.7 & 15.9 & 6.3 & 3.8 & 18.4 & 15.0 \\
\hline Middle East & 18.8 & 14.5 & 10.0 & 10.1 & 1.0 & 2.9 & 26.3 & 37.8 \\
\hline Western Hemisphere & 2.1 & 1.6 & 11.6 & 12.1 & 2.8 & 2.6 & 15.8 & 28.4 \\
\hline
\end{tabular}

Source: Calculated from Direction of Trade, IMF (2005, CD-ROM).

Note: developing countries columns do not add up to 100 since transitional economies are excluded.

developed economies rose from 40 per cent to 54.7 per cent, whereas that of India declined from 59.5 per cent to 52.4 per cent (Table 1). It is important to note that average decadal growth rates of Indian exports to developing countries have increased from 12.2 per cent during $1985-94$ to 16.5 per cent during 1995-2004, whereas similar rates for developed countries have declined from 13.6 per cent to 8.9 per cent during the corresponding periods. Though China has maintained a higher export rate with developed countries as compared with developing countries during both the decades, the broad trends in export growth rates have been similar to that of India.

Both China and India have shown their increased import dependence on developing countries by switching their sources of imports from developed to developing countries (Table 1). Between the periods 1985-94 and 1995-2004, the share of India's imports from developed countries declined from 56.4 per cent to 43.1 per cent, whereas it increased from 42.1 per cent to 43.3 per cent with developing countries during the same periods. The situation is clearer in the case of China than India.

The trade of both China and India is heavily concentrated in the Asian region. Almost half of China's exports were destined to developing Asia during the period 1985-94, and the dominance of developing Asia continued during 1995-2004. India's export performance is similar to that of China, and India's export share with the region increased by one and a half times between the two periods. Both countries have shown similar kinds of responses in regard to imports. Developing Asia continued to be the most attractive source for China's imports, increasing from 30 per cent during 1985-94 to 37 per cent during the period 1995-2004. Similarly India's imports from developing Asia saw a near twofold increase between the periods 1985-94 and 1995-2004. The share of China's and India's imports 
Table 2: Market access in India and China in 2002

\begin{tabular}{|c|c|c|c|c|c|c|c|c|c|}
\hline \multirow{2}{*}{\multicolumn{2}{|c|}{ Section Description }} & \multicolumn{4}{|c|}{ Import of China } & \multicolumn{4}{|c|}{ Import of India } \\
\hline & & D/ed & D/ing & LDCs & Trans & D/ed & D/ing & LDCs & Trans \\
\hline । & Live animals and animal products & 0.76 & 0.78 & 0.54 & 5.38 & 0.08 & 0.08 & 0.46 & 0.04 \\
\hline$\|$ & Vegetable products & 0.68 & 2.07 & 0.52 & 0.26 & 1.33 & 2.14 & 35.25 & 2.32 \\
\hline III & Animal or vegetable fats and oils & 0.15 & 0.89 & 0.09 & 0.00 & 0.03 & 8.39 & 3.44 & 0.06 \\
\hline IV & Prepared foodstuff, beverages, etc. & 0.48 & 0.89 & 0.13 & 0.33 & 0.21 & 0.57 & 1.63 & 0.05 \\
\hline V & Mineral products & 3.17 & 10.28 & 86.58 & 14.87 & 4.92 & 8.41 & 6.21 & 5.07 \\
\hline VI & Products of chemicals & 9.16 & 8.15 & 0.41 & 12.42 & 9.12 & 13.47 & 19.90 & 19.03 \\
\hline VII & Plastics and articles thereof & 4.89 & 8.73 & 0.33 & 3.15 & 2.65 & 2.98 & 1.59 & 4.69 \\
\hline VIII & Raw hides and skins, leather, etc. & 0.95 & 1.46 & 0.55 & 0.36 & 0.46 & 0.43 & 1.56 & 0.41 \\
\hline IX & Wood and articles of wood & 0.64 & 1.32 & 8.04 & 9.31 & 0.14 & 1.22 & 8.51 & 0.09 \\
\hline$x$ & Pulp of wood or of other fibres & 2.27 & 2.69 & 0.00 & 4.39 & 2.22 & 1.96 & 2.17 & 8.53 \\
\hline$X I$ & Textile and textile articles & 4.66 & 6.36 & 1.26 & 0.50 & 2.09 & 4.83 & 10.30 & 1.52 \\
\hline XII & Footwear, headgear and umbrella & 0.06 & 0.19 & 0.01 & 0.01 & 0.06 & 0.08 & 0.10 & 0.02 \\
\hline XIII & Articles of stone, plaster, cement & 0.93 & 0.61 & 0.01 & 0.06 & 0.58 & 0.53 & 0.01 & 0.56 \\
\hline XIV & Natural or cultured pearls, jewellery & 0.66 & 0.38 & 0.09 & 0.19 & 36.38 & 15.59 & 2.21 & 3.15 \\
\hline$X V$ & $\begin{array}{l}\text { Base metals and articles of base } \\
\text { metal }\end{array}$ & 9.04 & 7.94 & 1.39 & 26.94 & 6.01 & 4.79 & 5.59 & 31.05 \\
\hline$X V$ & $\begin{array}{l}\text { Machinery and mechanical } \\
\text { appliances }\end{array}$ & 47.53 & 39.90 & 0.03 & 10.32 & 23.03 & 25.59 & 0.36 & 11.90 \\
\hline XVII & Vehicles, aircraft and vessels & 6.61 & 2.11 & 0.00 & 9.61 & 4.16 & 4.68 & 0.36 & 6.34 \\
\hline$X V I I I$ & $\begin{array}{l}\text { Optical, photograph and } \\
\text { cinematography }\end{array}$ & 6.17 & 4.54 & 0.02 & 0.30 & 3.99 & 2.70 & 0.01 & 1.37 \\
\hline XIX & Arms and ammunition & 0.00 & 0.00 & 0.00 & 0.00 & 0.01 & 0.00 & 0.00 & 0.08 \\
\hline$X X$ & $\begin{array}{l}\text { Miscellaneous manufactured } \\
\text { articles }\end{array}$ & 0.44 & 0.33 & 0.02 & 0.07 & 0.30 & 0.54 & 0.20 & 0.06 \\
\hline$X X I$ & $\begin{array}{l}\text { Works of art collectors' pieces } \\
\text { Total }\end{array}$ & $\begin{array}{l}0.74 \\
100.0\end{array}$ & $\begin{array}{l}0.38 \\
100.0\end{array}$ & $\begin{array}{l}0.00 \\
100.0\end{array}$ & $\begin{array}{l}1.52 \\
100.0\end{array}$ & $\begin{array}{l}2.25 \\
100.0\end{array}$ & $\begin{array}{l}1.03 \\
100.0\end{array}$ & $\begin{array}{l}0.11 \\
100.0\end{array}$ & $\begin{array}{l}3.65 \\
100.0\end{array}$ \\
\hline
\end{tabular}

Source: Calculated from PCTAS-1998/2002, UNCTAD, ITC, World Bank and WTO, Geneva.

D/ed - developed countries; D/ing - developing countries; LDCs - least developed countries;

Trans - transitional countries. The country grouping is formed on the basis of UN statistical division.

has also increased for other developing regions such as Africa and the Middle East.

Surge in trade of these two countries in Asia is partly because of their presence in the continent and also because of trade liberalisation under multilateral and regional agreements, particularly the latter. ${ }^{1} \mathrm{~A}$ number of new regional trading arrangements have been established, including regional and bilateral trading arrangements (e.g. Bangladesh India Myanmar Sri Lanka Thailand Economic Cooperation (BIMSTEC); India-Singapore Comprehensive Economic Cooperation (CEC); India-Thailand CEC; India-Sri Lanka CEC; India-ASEAN Free Trade Agreement (FTA); China-ASEAN FTA; China-Japan
FTA; China-Singapore FTA) to complement preexisting agreements (e.g. ASEAN, SAARC and the Bangkok Agreement). These developments have contributed to increased trade with other regional economies (Mohanty 2005b). There are strong initiatives to form an Asian Economic Community, which would further consolidate the economic strength of both the countries (Kumar 2004).

\subsection{Disaggregating trade flows}

The rapid growth and large size of China and India, allied to growing trade liberalisation, has provided a substantial market for other developing economies. Considered by product-classification and the type 
of exporting economy, the imports of China and India are diversified (Table 2). The share of imports sourced from LDCs by these two countries is much lower than the other three broad country-groups (developed, developing and transitional economies), and is sectorally concentrated. In contrast, developing countries and transitional countries have a strong presence in several sectors, and in some sectors (particularly primary products) both China and India are heavily dependent on imports from LDCs. Mineral imports constituted 87 per cent of the total in 2002. India also imported substantial amounts of vegetable products from LDCs in the same year. Wood products, textiles, natural gems, base metals and some machinery items, and although this data is not sufficiently disaggregated, it is evident

Table 3: Market access in India and China for the end-use products: 1998-2002 (\%)

\begin{tabular}{|c|c|c|c|c|c|c|c|}
\hline \multirow{3}{*}{$\begin{array}{l}\text { End-use } \\
\text { code }\end{array}$} & \multirow{3}{*}{ Description } & \multicolumn{6}{|c|}{ India } \\
\hline & & \multicolumn{4}{|c|}{ Growth (\%) } & \multicolumn{2}{|c|}{ Share $(\%)^{*}$} \\
\hline & & D/ing & LDCs & Trans & D/ing & LDCs & Trans \\
\hline 0 & Foods, feeds and beverages & 0.27 & 13.24 & -7.92 & 10.88 & 38.42 & 2.15 \\
\hline 00 & Agricultural & 0.10 & 14.82 & -8.16 & 10.71 & 38.08 & 2.12 \\
\hline 01 & Non-agricultural products & 19.03 & -18.11 & 0.00 & 0.17 & 0.33 & 0.03 \\
\hline 1 & Industrial supplies and materials & -8.19 & 15.31 & 3.63 & 46.58 & 52.25 & 71.02 \\
\hline 10 & Fuels and lubricants & -21.8 & 256.77 & 15.05 & 4.31 & 1.61 & 2.35 \\
\hline 11 & Paper and paper base stocks & -0.05 & 8.15 & 3.49 & 2.15 & 5.88 & 6.90 \\
\hline 12 & Agri. product, textile sup. and chem. & 2.88 & 17.54 & -3.90 & 20.52 & 30.97 & 21.16 \\
\hline 13 & Selected building materials, excl. metal & 13.31 & 8.32 & 148.04 & 0.77 & 4.49 & 0.14 \\
\hline 14 & $\begin{array}{l}\text { Unfinished metal products associated with } \\
\text { durable goods }\end{array}$ & 6.96 & 19.94 & 7.67 & 15.23 & 5.15 & 31.21 \\
\hline 15 & $\begin{array}{l}\text { Finished metal products associated with } \\
\text { durable goods }\end{array}$ & 2.66 & 21.34 & -5.78 & 1.05 & 1.02 & 2.27 \\
\hline 16 & $\begin{array}{l}\text { Non-metallic products associated with } \\
\text { durable goods }\end{array}$ & 7.15 & 2.54 & 43.33 & 2.56 & 3.13 & 6.98 \\
\hline 2 & Capital goods, except automotive & 25.81 & 288.25 & 20.84 & 28.32 & 1.42 & 15.63 \\
\hline 20 & Electric generating and electric equipment & 20.90 & 149.24 & 30.37 & 2.77 & 0.21 & 2.06 \\
\hline 21 & Non-electric machinery & 21.91 & 236.34 & 36.89 & 20.18 & 0.87 & 12.89 \\
\hline 22 & $\begin{array}{l}\text { Transport, equipment and spacecraft, } \\
\text { excl. auto }\end{array}$ & 55.20 & 0.00 & -17.81 & 5.38 & 0.34 & 0.69 \\
\hline 3 & Capital goods, excl. non-automotive & 21.01 & 95.18 & 395.40 & 0.76 & 0.04 & 4.05 \\
\hline 30 & Automotive vehicles, parts and engines & 21.01 & 95.18 & 395.40 & 0.76 & 0.04 & 4.05 \\
\hline 4 & Consumer goods & 36.74 & 26.24 & 50.95 & 12.61 & 7.86 & 6.35 \\
\hline 40 & Non-durables, manufactures, excl. rugs & 16.69 & 27.12 & 33.34 & 2.40 & 5.50 & 3.30 \\
\hline 41 & Durables, manufactures, excl. automotive & 29.58 & 247.86 & 89.40 & 4.84 & 0.35 & 2.64 \\
\hline 42 & $\begin{array}{l}\text { Cons. durable and non durable, } \\
\text { manufactures }\end{array}$ & 67.58 & 18.08 & 77.89 & 5.37 & 2.00 & 0.42 \\
\hline 5 & Other goods & 67.97 & 52.16 & 70.90 & 0.85 & 0.02 & 0.79 \\
\hline \multirow[t]{2}{*}{50} & Imports, NES & 67.97 & 52.16 & 70.90 & 0.85 & 0.02 & 0.79 \\
\hline & Total & 0.07 & 15.67 & 7.80 & 100.00 & 100.00 & 100.00 \\
\hline
\end{tabular}

Source: Calculated from PCTAS-1998/2002, UNCTAD, ITC, World Bank and WTO, Geneva.

D/ing - developing countries; LDCs - least developed countries; Trans - transitional countries;

NES - not elsewhere classified. The country grouping is formed on the basis of UN statistical division.

"Share figures for 2002. 
that China imports significant quantities of semimanufactured intermediate products from its East Asian neighbours (see Lall and Albaladejo 2003). If both countries continue to deepen trade liberalisation, a large market can be opened up in diversified sectors. It is important to note that the sectors important to developing countries are not the same for LDCs and therefore developing

Table 3 (Cont.)

\begin{tabular}{|c|c|c|c|c|c|}
\hline \multicolumn{6}{|c|}{ China } \\
\hline \multicolumn{3}{|c|}{ Growth (\%) } & \multicolumn{3}{|c|}{ Share $(\%)^{*}$} \\
\hline D/ing & LDCs & Trans & D/ing & LDC & Trans \\
\hline 14.37 & 35.34 & 24.65 & 4.37 & 0.97 & 5.97 \\
\hline 11.43 & 16.69 & 7.44 & 3.64 & 0.49 & 0.24 \\
\hline 41.25 & 86.91 & 25.78 & 0.73 & 0.48 & 5.73 \\
\hline 18.20 & 69.41 & 44.35 & 46.12 & 98.78 & 72.78 \\
\hline 36.55 & 80.77 & 195.35 & 8.68 & 85.86 & 12.81 \\
\hline 8.70 & 80.24 & 36.92 & 2.74 & 4.86 & 4.79 \\
\hline 12.94 & 14.89 & 18.75 & 21.90 & 2.69 & 15.30 \\
\hline 10.16 & 13.11 & 234.81 & 1.36 & 3.17 & 8.79 \\
\hline 32.56 & 34.50 & 29.23 & 7.43 & 1.13 & 27.58 \\
\hline 11.89 & 304.30 & 195.22 & 1.74 & 0.82 & 2.34 \\
\hline 17.75 & -8.82 & 79.55 & 2.26 & 0.27 & 1.16 \\
\hline 48.68 & 11.29 & 16.45 & 42.94 & 0.03 & 13.62 \\
\hline 30.90 & 0.00 & 98.75 & 5.61 & 0.00 & 2.98 \\
\hline 53.17 & 9.49 & 10.13 & 34.44 & 0.03 & 6.00 \\
\hline 44.02 & 0.00 & 9.73 & 2.89 & 0.00 & 4.64 \\
\hline 52.13 & 0.00 & 62.04 & 0.95 & 0.00 & 0.89 \\
\hline 52.13 & 0.00 & 62.04 & 0.95 & 0.00 & 0.89 \\
\hline 14.88 & -10.44 & -3.15 & 5.35 & 0.22 & 1.08 \\
\hline 9.48 & -15.73 & -10.52 & 1.62 & 0.05 & 0.59 \\
\hline 16.30 & 61.80 & 24.14 & 3.41 & 0.08 & 0.42 \\
\hline 45.01 & -14.97 & 302.32 & 0.32 & 0.09 & 0.07 \\
\hline 1.15 & 0.00 & 184.93 & 0.27 & 0.00 & 5.66 \\
\hline 1.15 & 0.00 & 184.93 & 0.27 & 0.00 & 5.66 \\
\hline 27.13 & 67.74 & 38.09 & 100.00 & 100.00 & 100.00 \\
\hline
\end{tabular}

countries are not competing with LDCs in the same sectors for gaining market access in Chinese and Indian markets.

According to the Organisation for Economic Cooperation and Development (OECD) forecast, the global share of Chinese exports is likely to increase from the current level of 6 per cent in 2005 to 10 per cent in 2015 (OECD 2005). India's exports have reached US\$80bn in 2004-05 and are expected to reach US\$150bn or more by 2009-10 (RIS 2005). Many of these exports are dependent on imports. In assessing this, we have used Trade Analysis System on PC (PC TAS), ITC/UNCTAD/WTO (UNCTAD et al. 2005) bilateral data at the six-digit HS level, and concorded them with five-digit enduse product classification.

The structure of imports differs significantly across country groupings as shown in Table 4 . As far as LDCs are concerned, both the countries have provided a market for industrial supplies and materials, and consumer goods. India has substantial imports of agricultural raw materials from LDCs. However, the bulk of imports from LDCs have been of industrial intermediates, often subsequently processed for export to third country markets; this is especially the case for China's exports of manufactures (Lall and Albaladejo 2003). India's import is concentrated in agro-raw materials for textiles and chemicals, unfinished metals associated with durable goods and non-metal associated with durable goods. The share of LDCs' exports of consumer goods to India is larger than that of China. In most of these segments, the growth rates of imports from LDCs were very rapid between 1998 and 2002. Imports from developing countries have been more diversified than the LDCs. Between 88-95 per cent is concentrated in three broad enduse sectors: industrial supplies and materials, capital goods (except automotive) and consumer goods. As noted earlier, industrial intermediate constitutes the maximum share in the total imports of both the countries. Unlike the case of trade with LDCs, there could be some possibility of clash of interests between developing countries and LDCs to gain market access in industrial supplies and materials.

\section{Innovation and transfer of technology}

The discussion in the previous section throws light on the potential impact of China and India on developing countries and LDCs through the trade 


\begin{tabular}{|c|c|c|}
\hline & 1998 & 2003 \\
\hline Sweden & $3.62^{*}$ & $4.27^{\dagger}$ \\
\hline Finland & 2.88 & 3.51 \\
\hline Germany & 2.31 & $2.50^{\star}$ \\
\hline France & 2.17 & 2.19 \\
\hline Austria & 1.78 & 2.19 \\
\hline EU & 1.82 & 1.93 \\
\hline UK & 1.81 & $1.87^{\ddagger}$ \\
\hline Italy & 1.07 & $1.16^{\ddagger}$ \\
\hline US & & 2.76 \\
\hline Japan & & 3.12 \\
\hline China & & $1.93^{\star *}$ \\
\hline India & & $1.56^{* \star *}$ \\
\hline
\end{tabular}

Source: Financial Times (19 July 2005); Planning Commission (2003).

“Estimate; ${ }^{\star 2} 2001$ figure; ${ }^{\star 2} 2002$ figure; ${ }^{*}$ Estimate for 2010; ${ }^{* * *}$ Estimate for 2007.

conduit (Asian Driver 1 in the terminology of Schmitz's article in this IDS Bulletin). But with a focus on the future it is also likely that the rise of innovative capabilities in China and India (Asian Driver 3 in Schmitz's terminology) will be of growing importance (Chaturvedi 2005, 1997). This is especially likely to be relevant to poverty-related concerns in the case of innovation in the agricultural sector where biotechnology and other knowledgeintensive technological advances are being made, and in pharmaceuticals. In both China and India in previous generations the state has played a major role in the generation of knowledge-intensive innovation; in the current period, the private sector has grown in importance.

In India, there are more than 150 international companies undertaking R\&D. In 2005, the revenues from product development and R\&D services stood at US $\$ 3$ bn (US $\$ 2.3$ bn in 2004 ). ${ }^{2}$ This rise in $R \& D$ contrasts with the dynamic in many developed economies (such as the EU; Financial Times, 19 July 2005) where there are concerns about declining $R \& D$ expenditure in general and the private sector in particular. R\&D investment across the EU on average is 2.2 per cent of GDP (Table 2). The corresponding figures for the US and Japan are 2.76 and 3.12 per cent, respectively. In the case of China, the $R \& D$ ratio is likely to be 1.93 per cent by 2010 and for India 1.56 per cent by 2007. An EU report expresses concern about India and China: 'China is within five years likely to devote at least the same share of its wealth to research as the EU' (Financial Times, 19 July 2005).

In the case of China, a detailed roadmap for a pre-eminent position in world knowledge economy was drawn by the Chinese Academy of Sciences in 1998 (China Science and Technology Newsletter No 384,10 November 2004). According to this, China would strive to become one of the ten major economies in terms of knowledge innovation, patent competitiveness, and science and technology. This objective is being pursued in three phases. In the starting phase (1998-2001), eight knowledge innovation bases were established. In the second period (2001-05) a fully fledged implementation will be staged in some 80 institutes, forming an innovative national research innovation system. The last period between 2006-10 is envisaged as an enhancement phase, seeing the materialisation of the project's general goals, and greatly enhanced innovation capability. The new International Science and Technology Cooperation (ISTC) approach that emphasises shifting from passive to active stance and initiating cooperation projects also suggests closely linking up with other developing countries. During the period 1991-2004, China signed 48 Memorandum of Understanding (MoUs) with various countries on science and technology (China Science and Technology Newsletter, May 2004).

India has also enhanced the focus on new technology and their possible convergences, for instance, promoting bioinformatics in a major way based on the Information and Communication Technology (ICT) success. This may give a major boost to the manufacturing and service sectors. India and China are encouraging FDI for advanced areas in the frontier technologies such as the biomedical sector, where there is a need for a combination of manufacturing and serviceproviding abilities. Eli Lilly \& Company, the US $\$ 1$ lbn US pharmacy transnational corporation, is planning to appoint an Asia-specific global team to look at R\&D opportunities in China and India. The company, which has put India on its global $R \& D$ map as a very important location for its global strategies, has plans to license potential research products in biopharmaceuticals and vaccines, in addition to conducting clinical research in India for new products and sourcing bulk drugs from the 
country (Business Standard, 22 August 2005). Similarly, Mirco Labs of Bangalore (India) has entered into a marketing and production alliance with LG Life Sciences of Korea of a drug for ophthalmologic surgeries, which is produced with the help of recombinant technology (Business Standard, 24 August 2005).

India and China, it seems, have great faith in the Chinese proverb, 'if you want one year of prosperity, grow grain. If you want prosperity for ten years grow trees and if you want prosperity of 100 years grow manpower' (The Economist, 30 July 2005), and this has been reflected in their links with each other and with other developing economies. There are several joint ventures coming up between Indian computer institutes and Chinese universities for training students in English language and computer science. For instance, the Central South Forestry University in Hunan Province and a Bangalore-based institute, DSI Computer Centre, have signed an MoU to this effect. DSI has also signed a similar agreement with Wuhan University located in Hubei Province (Economic Times, 8 August 2005). China has taken specific initiatives to establish ties with other countries to strengthen the science and technology linkages. So far, educational agreements have been signed between China and more than 40 Asian and African countries, including Japan, North Korea, South Korea, Mongolia, Vietnam, Singapore, Malaysia, Thailand, India, Pakistan, Iran, Israel, Saudi Arabia, Yemen, Egypt, South Africa and Kenya. They are undertaking mutual visits of delegations, exchanges of students and scholars, interinstitutional collaborations, exchange of teaching materials and cooperation in language teaching.

India is beginning to provide assistance to other developing countries in addressing their agriculturerelated problems. Vietnam, the global leader in the production and export of pepper, has sought India's

\section{Notes}

1. For details about Indian gains from South Asia, see Mohanty $(2003,2005 a)$ and for recent developments in the RTA, see RIS (2004).

2.knowledge@wharton.upenn.edu (http://knowledge. wharton.upenn.edu/index.cfm?fa=viewArticle\&rid=1286). assistance for combating diseases that have begun to attack pepper vines. Being a late entrant in pepper production, Vietnam lacks expertise and knowledge in combating diseases and needs to be equipped with scientific farming methods (The Financial Express, 29 August 2005). India also helped in establishing one of the leading rice research institutes in Vietnam, a tea research institute in Colombo, biotechnology research institute in Indonesia and a tropical plant disease institute in Zimbabwe.

\section{Conclusion}

The combined size of the Sino-Indian economy is large and expanding. There is considerable scope for growing economies in the developing world and LDCs to benefit from the continued process of trade expansion in these two countries. Given the risk of a slowdown in the global economy, China and India have an interest in sustained growth in the developing world in general, and in Asia in particular. There are particular opportunities with regard to the least developed economies. The LDCs are producers of a few industrial intermediate inputs, which are commonly used by these two countries. Very often, supply barrier and lack of quality in exportable items have constrained the export prospects in various potential markets (Majumdar 2005). If these issues are addressed, there is scope for significant exports to both China and India. Second, most of these countries do not compete directly with China and India in global markets, and thus there is scope for close cooperation in multilateral negotiations. Third, China and India may be useful in improving the structural impediments being faced by the LDCs in various areas related to agricultural and industrial production. This may be achieved by access to technology, FDI and technical assistance. 


\section{References}

Burton, D., 2005, 'Asia's growing role in world economy', Financial Times, 1 June, London

Chaturvedi, S., 2005, 'Dynamics of biotechnology research and industry in India: statistics, perspectives and key policy issues', OECD STI Working Papers Series 6, Paris: Directorate for Science, Technology and Industry

Chaturvedi, S., 1997, 'At China's Table: Food Security Options', presentation made at seminar on 'Documents of China 2020', 8 November, Research and Information System for the Developing Countries (RIS), New Delhi

Kumar, N. (ed.), 2004, Towards an Asian Economic Community: Vision of a New Asia, RIS, New Delhi and Singapore: Institute for South-East Asian Studies (ISEAS)

Lall, S. and Albaladejo, M., 2003, 'China's manufactured export surge: the competitive implications for East Asia', prepared for the East Asia Dept of the World Bank, mimeo, Oxford: Queen Elizabeth House

Majumdar, S.K., 2005, 'India astride a supply side revolution', The Hindu Business Line, 23 August

Mohanty, S.K., 2005a, 'Is South Asian economic cooperation sustainable?: strategy for meaningful transition from SAPTA to SAFTA', paper presented at the 8th GTAP Conference, Ls beck, Germany, 9-11 June

Mohanty, S.K., 2005b, 'Prospects of India-China FTA in the new millennium: an exploratory analysis,' mimeo, New Delhi: Research and Information System
Mohanty, S.K., 2003, 'Regional trade liberalisation under SAPTA and India's trade linkages with South Asia: an empirical assessment', paper presented in 'The Expert Group Meeting on Regional Trading Agreements in Asia and Pacific' for the UNESCAP, Bangkok, 30-31 January

OECD, 2005, Economic Survey of China, Paris: Organisation for Economic Co-operation and Development

Palley, T.I., 2004, 'External contradictions of the Chinese development model: why China must abandon export-led growth or risk of global economic contraction', Working Paper, University of Massachusetts: Political Economy Research Institute

Planning Commission, 2003, 'S\&T in India', Eleventh Five Year Plan Document, New Delhi: Government of India

RIS, 2005, Towards an Employment-Oriented Export Strategy: Some Preliminary Explorations, New Delhi: Research and Information System (RIS) for the Developing Countries

RIS, 2004, Future Direction of BIMSTEC: Towards a Bay of Bengal Economic Community, New Delhi: Research and Information System (RIS) for the Developing Countries

United Nations Conference on Trade and Development (UNCTAD), 2005, PCTAS 19982002, CD-ROM, Geneva

World Bank, 2005, World Development Indicators 2005 CD-ROM, Washington, D.C.: World Bank 